\title{
Application of amino acids and micronutrients on yield of common bean (Phaseolus vulgaris L.).
}

\author{
André Henrique Gonçalves ${ }^{1}$, Anielli Souza Pereira ${ }^{1}$, Jefferson Henrique Gomes Malvino², \\ Valdere Martins dos Santos ${ }^{1}$ and Maria Alice Figueiredo Martins Bonilha ${ }^{2}$ \\ ${ }^{1}$ Departamento de Agronomia; Universidade Federal do Tocantins; 77402-970; Gurupi - TO - Brasil. \\ ${ }^{2}$ Departamento de Ciências Agrárias; Faculdades Associadas de Uberaba; 38061-500; Uberaba - MG - Brasil.
}

\begin{abstract}
Aiming to verify the effects of the use of sources of amino acids associated to micronutrients on the final yield of common bean, was conducted an experiment at FAZU in Uberaba-MG, using Carioca kind of bean, cultivar Pérola. The design was in randomized blocks with eight treatments and four repetitions. The sowing was done in August 18, 2008, the final stand of 240.000 plants ha ${ }^{-1}$ Fertilization was held with 8-28-16 and coverage with urea. The treatments were constituted of T1: witness; T2: seed treatment (B: 0,1\%; Cu: 0,1\%; Mo: 2,\%; Zn: 4,6\%); T3: seed treatment + foliar fertilization at 25 DAE (B: 0,3\%; Mn: 2,\%; Mo: 1\%; Zn: 3\% + amino acids); T4: seed treatment + foliar application of amino acids at 25 DAE; T5: seed treatment + foliar application of amino acids in the pre and post-bloom (40 and 50 DAE); T6: foliar fertilization at 25 DAE (B: 0,3\%; Mn: 2\%; Mo: 1,\%; Zn: 3\% + amino acids); T7: foliar application of amino acids at 25 DAE; T8: foliar application (B: 0,3\%; Mn: 2\%; Mo: 1,\%; Zn: $3 \%+$ amino acids) in the pre and post-bloom (40 and 50 DAE). It was evaluated: final yield, number of pods/plants, number of grains/pods and the mass of 100 grains. The results did not show relevant difference.
\end{abstract}

Key-words:Phaseolus vulgaris, foliar fertilization, micronutrients, amino acids and plant physiology

\section{INTRODUCTION}

The common bean (Phaseolus vulgaris L.), despite being a basic constituent in the diet for the most of Brazilian population, showed from 2002 to 2007 , a supply very variable of the product, which has caused significant disturbance and inconstancy in its business scenario(Fancelli andDouradoNeto, 2007).

By presenting a relevant role in the diet of the Brazilian, the common bean is one of the agricultural products of utmost importance economic and social, mainly due to the labor using during the crop cycle. It is estimated that only in Minas Gerais are used in bean crop about 7 million of man/days in its cycle of production, involving about 295 thousandproducers(EMBRAPA, 2007).

The productivity of the common bean is very associated to the availability of nutrients in the soil and the way of availability of nutrients is strictly related to the availability of water, $\mathrm{pH}$ and minerals because all mineral nutrients move in the

Author for correspondence: andrehg@uft.edu.br either by diffusion or mass flow (Fancelli and DouradoNeto, 2007).

The objective of this study was compare the use of sources of amino acids associated to micronutrients in an isolated way and combined in the development and productivity of common bean.

\section{MATERIAL AND METHODS}

The experiment was conducted in the experimental area of the demonstration farm of FAZU FaculdadesAssociadas de Uberaba (Associated Faculties of Uberaba), under center pivot, in the agricultural year of 2008 , located at $19^{\circ} 44^{\prime}$ 'South latitude and $47^{\circ} 57^{\prime}$ 'West longitude and altitude of $780 \mathrm{~m}$. The climate according to the classification of Koppen classified as Aw (hot and humid tropical climate with cold and dry winter), with an annual rainfall of $1750 \mathrm{~mm}$ and average annual temperature of $23{ }^{\circ} \mathrm{C}$. The soil is classified as dystrophic red latosol (oxisol).

erimental design used was randomized vith eight treatments and four repetitions, 
total of 32 plots. The plot was composed by six rows of $5 \mathrm{~m}$ of length, spaced $0,5 \mathrm{~m}$, being the floor area the two central rows, eliminating $0,5 \mathrm{~m}$ at each end.
The fertilization in the furrow sowing was performed in a continuous bead, using $380 \mathrm{~kg} \mathrm{ha}^{-1}$ of the formulation 08-28-16 of NPK, taking into consideration the soil chemical properties, according to Table 1 .

Table 1. Analysis of soil of the experimental area $(0-20 \mathrm{~cm})$.

\begin{tabular}{|c|c|c|c|c|c|c|c|c|}
\hline $\mathrm{pH}$ & Mo & $\mathrm{P}$ & $\mathrm{K}$ & $\mathrm{H}+\mathrm{Al}$ & $\mathrm{Ca}$ & $\mathrm{Mg}$ & SB & $\mathrm{V}(\%)$ \\
\hline & & \multicolumn{2}{|c|}{$\mathrm{mg} \mathrm{dm}^{-3}$} & \multicolumn{3}{|c|}{$\left(\mathrm{cmoldm}^{-3}\right)$} & & \\
\hline 6,29 & 1,47 & 11,1 & 72 & 2,3 & 1,66 & 0,52 & 2,36 & 50,69 \\
\hline $\mathrm{Wa}$ & Lo & Lo & M & Lo & M & $\mathrm{M}$ & $\mathrm{M}$ & $\mathrm{M}$ \\
\hline
\end{tabular}

$\mathrm{Wa}=$ weak acidity; Lo = Low; M = Medium; Interpretation according to Ribeiro et al., (1999).

It was used the cultivar Pérola carioca type, that has the normal cycle of 85 to 100 days, indeterminate and prostrate growth habit.

The sowing was held manually in the planting furrows on August 18, 2008 considering the rainy season, but sown late, in an area of $560 \mathrm{~m}^{2}$.

After the emergence (10 Days After Sowing) of plants, when they presented the first leaf stage, was performed a thinning leaving 12 plants per linear meter, aiming for a final stand of 240.000 plantsha ${ }^{-1}$.

Two coverage fertilizations were also conducted, being the first at 20 days after the emergence (DAE), applying 45,96 kg ha-1 of urea by throwing on the sides of the planting lines and again at 30 DAE the same quantity of the fertilizer.

It was used the center pivot irrigation, applying a total depth of water of $550 \mathrm{~mm}$.

The seeds were treated with insecticide Tiametoxam $\left(300 \mathrm{ml} 100 \mathrm{~kg}\right.$ of seeds $\left.{ }^{-1}\right)$ and the fungicides Fludioxonil + Metalaxil-M (200 $\mathrm{ml} 100$ $\mathrm{kg}$ seeds $\left.^{-1}\right)$. In all plots were also mademanualweeding at 4 and 16 DAE.

Beyond the manual weeding for control of weeds, was used the pre-emergent herbicideTrifluralina $\left(1,8 \mathrm{~L} \mathrm{ha}^{-1}\right)$ the following day after sowing, with the backpack pump, with a capacity of 20 liters and a spraying rod.
In relation to the phytosanitarymanagement, there was the monitoring of the culture, using the insecticides Abamectina $\left(0,2 \mathrm{~L} \mathrm{ha}^{-1}\right)$ at $25 \mathrm{DAE}$; Lambda-cialotrina $\left(250 \mathrm{ml} \mathrm{ha}^{-1}\right)$ at $35 \mathrm{DAE}$; Cipermetrina and Tiametoxam $\left(300 \mathrm{ml} \mathrm{ha}^{-1}\right)$ at 45 and $65 \mathrm{DAE}$ and the fungicide Azoxistrobina (120 $\left.\mathrm{g} \mathrm{ha}^{-1}\right)+$ mineral Oil $\left(0,5 \mathrm{~L} \mathrm{ha}^{-1}\right)$ at 25,45 and 65 DAE.

The treatments consisted to hold in differentphenologicalstages of plant,applications using amino acids and foliar fertilizer (B:3,6g;Mn:16g;Mo:11,27g;Zn:37,17g), of joint ways with associations of both or in isolated ways. In some treatments, the seeds were treated with micronutrients (B: 0,24 g; Cu: 0,24 g; Mo: 4,96 g; $\mathrm{Zn}: 11,4 \mathrm{~g}$ ) and used in isolated ways, joint with amino acids, or with association of both, according to Table 2 .

To evaluate the yield, the plants were desiccated at 98 DAE with the herbicide Dibrometodiquate $(2,5$ $\left.\mathrm{L} \mathrm{ha}^{-1}\right)+$ mineral Oil $\left(0,5 \mathrm{~L} \mathrm{ha}^{-1}\right)$.

The harvest was held at 110 DAE due to the coincidence with the rainy period.To the analyses of the final stand, were counted all the plants of the floor area of plots.

The characteristic mass of 100 grains was obtained by weighing grains samples of the pods harvested in the floor area of each plot. 
Table 2.Treatmentsused.

\begin{tabular}{|c|c|c|c|}
\hline \multicolumn{2}{|c|}{ Treatment(g.100 kg of seed $\left.{ }^{-1}\right)$} & \multirow{2}{*}{$\begin{array}{c}\text { Foliar Fertilization }\left(\text { l.ha }^{-1} \text { containing }\right. \\
\text { the equivalent values })\end{array}$} & \multirow[t]{2}{*}{ Application time } \\
\hline 1 & Without supplementation & & \\
\hline 2 & $\begin{array}{c}\mathrm{B} \text { and } \mathrm{Cu}: 0,24 \text {; Mo: 4,96; } \\
\mathrm{Zn:} 11,4\end{array}$ & & \\
\hline 3 & $\begin{array}{c}\mathrm{B} \text { and } \mathrm{Cu}: 0,24 ; \mathrm{Mo:} 4,96 ; \\
\mathrm{Zn:} 11,4\end{array}$ & $\begin{array}{c}\text { B: 3,6; Mn: 16; Mo: } 11,27 ; \mathrm{Zn}: \\
\text { 37,17 + amino acids }\end{array}$ & $25 \mathrm{DAE}$ \\
\hline 4 & $\begin{array}{c}\mathrm{B} \text { and } \mathrm{Cu}: 0,24 ; \mathrm{Mo:} 4,96 ; \\
\mathrm{Zn:} 11,4\end{array}$ & Amino acids & $25 \mathrm{DAE}$ \\
\hline 5 & $\begin{array}{c}\mathrm{B} \text { and } \mathrm{Cu}: 0,24 ; \mathrm{Mo:} 4,96 ; \\
\mathrm{Zn:} 11,4\end{array}$ & Amino acids & $\begin{array}{l}\text { Pre-flowering (45 DAE) } \\
\text { andpost-flowering (50 DAE) }\end{array}$ \\
\hline 6 & & $\begin{array}{c}\text { B: 3,6; Mn: 16; Mo: 11,27; Zn: } \\
\text { 37,17 + amino acids }\end{array}$ & $25 \mathrm{DAE}$ \\
\hline 7 & & Amino acids & $25 \mathrm{DAE}$ \\
\hline 8 & & $\begin{array}{c}\text { B: 3,6; Mn: 16; Mo: } 11,27 ; \mathrm{Zn}: \\
\text { 37,17 + amino acids }\end{array}$ & $\begin{array}{l}\text { Pre-flowering (45 DAE) and } \\
\text { post-flowering (50 DAE) }\end{array}$ \\
\hline
\end{tabular}

The determination of the humidity was performed through the electrical conductivity and the values obtained were corrected for humidity of $13 \%$.

There was obtained, thus, the yield of each plot using the equations:

$$
\begin{gathered}
\mathrm{Y}=\frac{(\mathrm{P} \times \mathrm{Vp} \times \mathrm{Gp} \times \mathrm{M})}{100000} \\
\mathrm{Yc}=\frac{[(\mathrm{Y} \times \mathrm{H}) \div \mathrm{Hr}] \times[(100-\mathrm{H})}{(100-\mathrm{Hr})]}
\end{gathered}
$$

In which $\mathrm{Y}$ refers to the yield in $\mathrm{kg} \mathrm{ha}^{-1}, \mathrm{P}$ to the population of plants (plants $\mathrm{ha}^{-1}$ ), $\mathrm{Vp}$ to the average number of pods per plant, Gpto the average number of grains per pod, $\mathrm{M}$ to the mass of 100 grains or seeds, Yc the yield $\left(\mathrm{kgha}^{-1}\right)$ corrected according to the humidity required, $\mathrm{H}$ to the humidity measured and $\mathrm{Hr}$ to the humidity required (in this case, 13\%).

The data were submitted to the analysis of variance by the program SISVAR and the comparison of the averages of the treatments, were performed by the Tukey test at $5 \%$ probability.

\section{RESULTS AND DISCUSSION}

The supplementation with nutrients either in the treatment of seeds or in the foliar fertilization did not influence significantly on development and yield of the common bean, as can be seen in Table 3.

However, the average yield obtained in the treatments with application of nutrients was superior than the obtained by the witness, showing a difference of more than $1000 \mathrm{~kg} \mathrm{ha}^{-1}$, with a highlight to the treatment 5 . The overall average was also higher than the average of Minas Gerais, that in the harvest 2008/09 was $1400 \mathrm{k} \mathrm{g} \mathrm{ha}^{-1}$ (AGRIANUAL, 2010). Wrucket al. (2005), Castro and Boaretto (2001), using nutrients in the treatment of seeds and via foliar obtained similar results to those found in this study. Results not relevant of productivity were also obtained with the application of nutrientes via foliar by Vieira et al. (2005), Kikuti and Tanaka (2005).

Table 3. Characters of development and productivity of the common bean. 


\begin{tabular}{cccccc}
\hline Treatment & Final stand & Yield(kg/ha) & Numberpods/plant & $\begin{array}{c}\text { Number } \\
\text { grains/pod }\end{array}$ & $\begin{array}{c}\text { Mass } \\
100 \text { grains }\end{array}$ \\
\hline 1 & $259500 \mathrm{a}$ & $1877,7 \mathrm{a}$ & $6,9 \mathrm{a}$ & $4,21 \mathrm{a}$ & $28,46 \mathrm{a}$ \\
2 & $242000 \mathrm{a}$ & $2974,5 \mathrm{a}$ & $9,1 \mathrm{a}$ & $4,74 \mathrm{a}$ & $29,14 \mathrm{a}$ \\
3 & $243500 \mathrm{a}$ & $2800,8 \mathrm{a}$ & $9,2 \mathrm{a}$ & $4,58 \mathrm{a}$ & $28,64 \mathrm{a}$ \\
4 & $265500 \mathrm{a}$ & $3113,9 \mathrm{a}$ & $9,4 \mathrm{a}$ & $4,30 \mathrm{a}$ & $29,81 \mathrm{a}$ \\
5 & $279500 \mathrm{a}$ & $3328,7 \mathrm{a}$ & $9,3 \mathrm{a}$ & $4,56 \mathrm{a}$ & $30,04 \mathrm{a}$ \\
6 & $254500 \mathrm{a}$ & $2645,5 \mathrm{a}$ & $8,3 \mathrm{a}$ & $4,20 \mathrm{a}$ & $29,87 \mathrm{a}$ \\
7 & $258000 \mathrm{a}$ & $2695,6 \mathrm{a}$ & $8,1 \mathrm{a}$ & $4,80 \mathrm{a}$ & $29,33 \mathrm{a}$ \\
8 & $243000 \mathrm{a}$ & $2775,1 \mathrm{a}$ & $8,0 \mathrm{a}$ & $4,86 \mathrm{a}$ & $28,25 \mathrm{a}$ \\
\hline Overall average & 255687,5 & 2776,45 & 8,53 & 4,53 & 29,19 \\
C.V (\%) & 20,94 & 30,14 & 20,47 & 14,40 & 7,25 \\
\hline
\end{tabular}

Averages followed by the same letter, in the column, do not differ by the Tukey test, at $5 \%$ probability.

The number of pods per plant is an important component in the determination of the production. Although there is no significant difference between the treatments, the witness showed a number of pods per plant relatively lower than the plants treated, and the treatments 4 and 5 obtained the best results. The number of grains per pod is a genetic characteristic and was not expected a nutritional effect on the increase of numbers ofgrains in the pods of bean, which was confirmed by the results obtained. A similar result was obtained by Lima et al. (1999) when testing the foliar application of micronutrients on common bean.

In the evaluation of mass of 100 grains, the treatment 5 was superior, but this result was not so expressive. Lima et al. (1999), also did not find variations in this variable. This shows that the highest increase in the productivity of the common bean was due to the increase in the number of pods.

\section{CONCLUSION}

The parameters evaluated did not show significant results when used treatment of seeds in isolation or associated to the foliar fertilization with micronutrients and/or amino acids, although there was an increase of more than $1000 \mathrm{~kg} \mathrm{ha}^{-1}$ in the productivity of the common bean.

\section{REFERENCES}

AGRIANUAL. (2010), Anuário da agricultura brasileira. São Paulo: Agra FNP., 318-323.

Castro, A. M. C. andBoaretto, A. E. (2001), Adubação foliar do feijoeiro com nutrientes, vitamina B1 e metionina. Scientia Agraria, 2, 117121.
EMBRAPA ARROZ E FEIJÃO. (2007), Origem e História do Feijão. Disponível em: http://www.cnpaf.embrapa.br/feijao/historia.htm. Acesso em: 20 fev.2010. $\begin{array}{lcr}\text { EMBRAPA } & \text { BRASÍLIA. } & \text { (2007), } \\ \text { Feijão:morfologia. } & \text { Disponível } & \mathrm{em}:\end{array}$ http://www.agencia.cnptia.embrapa.br/Agencia4/A G01/arvore/AG01_9_1311200215101.html.

Fancelli, A. L.and Dourado Neto, D. (2007), Produção de feijão. Piracicaba/SP: Livro ceres, 2007. $386 \mathrm{p}$.

Kikuti, H. andTanaka, R. T. (2005), Produtividade e qualidade de sementes de feijão em função da aplicação de aminoácidos e nutrientes. In: CONGRESSO NACIONAL DE PESQUISA De FEIJÃO. Goiânia-GO. Anais. Santo Antônio de Goiás: Embrapa Arroz e Feijão, 1, 2005.

Lima, S. F; Andrade, M. J. B; Carvalho, J. G. de. (1999), Resposta de feijoeiro à adubação foliar de boro, molibdênio e zinco. Ciência $e$ Agrotecnologia, 23,462-467.

Vieira, N.M.B.; Alves Júnior, J.; Silveira, L.S.M.; Andrade, M.J.B.; Carvalho, J.G. Adubação foliar com boro na cultura do feijoeiro. CONGRESSO NACIONAL DE PESQUISA DE FEIJÃO, 18-20 out., 2005, Goiânia-GO. Anais v. 1, Santo Antônio de Goiás: Embrapa Arroz e Feijão, 2005.

Wruck, F. J; Cobucci, T; Stone, L. F. Efeito do tratamento de sementes e da adubação foliar com micronutrientes na produtividade do feijoeiro. 
CONGRESSO NACIONAL DE PESQUISA DE FEIJÃO. Goiânia-GO. Anais. Santo Antônio de Goiás: Embrapa Arroz e Feijão, 1, 2005. 